\title{
PENGETAHUAN TENTANG HAZARD DALAM PEMBERIAN ASUHAN KEPERAWATAN UNTUK PENERAPAN KESELAMATAN DAN KESEHATAN KERJA
}

\author{
ANISYAH ISWARA \\ Fakultas Keperawatan Universitas Sumatera Utara \\ Email : anisyahiswara@gmail.com
}

\section{LATAR BELAKANG}

Kesehatan dan Keselamatan Kerja (K3) adalah upaya untuk memberikan jaminan keselamatan dan meningkatkan derajat kesehatan pekerja dengan cara pencegahan kecelakaan dan penyakit akibat kerja (PAK), pengendalian bahaya di tempat kerja, promosi kesehatan, pengobatan, dan rehabilitasi. Upaya penerapan K3 di rumah sakit menyangkut tenaga kerja, cara atau metode kerja, alat kerja, proses kerja, dan lingkungan kerja yang meliputi peningkatan, pencegahan, pengobatan, dan pemulihan. Penerapan Kesehatan dan Keselamatan Kerja (K3) di Indonesia diatur oleh Undang-Undang Republik Indonesia Nomor 13 Tahun 2003 tentang Ketenagakerjaan, sedangkan Kesehatan dan Keselamatan Kerja Rumah Sakit (K3RS) diatur oleh KEPMENKES RI Nomor 1087/MENKES/ SK/VIII/2010. Keselamatan dan Kesehatan Kerja (K3) pada umumnya bertujuan melindungi keselamatan dan kesehatanpekerja dalam mewujudkan produktivitas kerja yang optimal. Tujuan diterapkannya Keselamatan dan Kesehatan Kerja Rumah Sakit (K3RS) adalah terciptanya cara kerja, lingkungan kerja yang sehat, aman, nyaman, dan dalam rangka meningkatkan derajat kesehatan karyawan rumah sakit.

Tingkat pengetahuan tentang hazard dalam permberian asuhan keperawatan untuk penerapan keselamatan dan kesehatan kerja (K3) sangat penting dalam menjaga keselamatan dan kesehatan pasien dan perawat. Karena pengetahuan kesehatan dan keselamatan kerja (K3) yang baik dapat menurunkan agka kecelakaan. Adapun faktor yang dapat mempengaruhi tingkat pengetahuan hazard dalam pemberian asuhan keperawatan untuk menerapkan kesehatan dan keselamatan kerja yaitu pendidikan, usia dan lama kerja . Pendidikan dapat mempengaruhi pengetahuan tentang hazard karena semakin tinggi pendidikan seorang perawat maka pengetahuan yang dimilikinya akan semakin baik. Usia dapat mempengaruhi pengetahuan tentang hazard dalam menerapkan keselamatan dan kesehatan kerja karena usia dapat mempengaruhi tingkat kematangan seseorang dalam berpikir dan menangkap suatu hal yang pada akhirnya dapat meningkatkan pengetahuan seseorang. Lama kerja dilingkungan rumah sakit juga dapat mempengaruhi tingkat pengetahuan tentang hazard dalam menerapkan keselamatan dan kesehatan kerja, karena perawat dan tenaga medis yang bekerja lebih dari satu tahun cenderung lebih rendah dalam mengalami kecelakaan kerja. Oleh sebab itu pengetahuan keselamatan dan kesehatan kerja (K3 ) yang baik dapat menurunkan angka kecelakaan kerja hingga tercapainya zero accident di lingkungan rumah sakit. 


\section{METODE PENELITIAN}

Metode yang digunakan adalah metode kualitatif yaitu dengan cara "Literature Review dimana maksudnya dengan cara mengumpulkan beberapa data, menganalisis dan melakukan pengkajian dengan menggunakan jurnal, teksbook, google scholar yang berfokus pada metode pembelajaran yang berhubungan denga " Pengetahuan tentang hazard dalam pemberian asuhan keperawatan untuk penerapan keselematan dan kesehatan kerja" sehingga jurnal, text book, google scholar, google books yang digunakan dalam pengkajian dapat digunakan untuk mengetahui bagaimana pengetahuan tentang hazard dalam pemberian asuhan keperawatan untuk penerapan keselematan dan kesehatan kerja serta mengetahui bagaimana tingkat pengetahuan tentang hazard dalam permberian asuhan keperawatan untuk menerapkan keselamatan dan kesehatan kerja (K3 )yang digunakan untuk menerapkan keselamatan pasien sehingga tidak terjadi kecelakaan kerja, sehingga tercapainya penurunan angka kecelakaan kerja serta tercapainya zero accident di lingkungan rumah sakit.

\section{HASIL}

Berdasarkan dari tinjauan literatur tersebut dapat disimpulkan bahwa hasil penelitian ini menjawab seluruh tujuan dalam penelitian. Hasil penelitian ini meliputi pengkajian data tentang Peran keluarga menjaga keselamatan pasien di ruang rawat inap rumah sakit. Dalam penelitian tinjauan literatur beberapa metode pengumpulan data dapat bermanfaaat dalam meningkatkan pengetahuan tentang hazard dalam pemberian asuhan keperawatan untuk penerapan keselematan dan kesehatan kerja dan dapat mengindari kecelakaan kerja contonya tertusuk jarum suntik , Sehingga tercapainya penurunan angka kecelakaan kerja serta tercapainya zero accident di lingkungan rumah sakit . 


\section{PEMBAHASAN}

Pengetahuan tentang hazard dalam pemberian asuhan keperawatan untuk penerapan keselamatan dan kesehatan kerja dapat diperoleh melalui pengalaman, baik pengalaman sendiri ataupun pengalaman orang lain. Pengetahuan kesehatan dan keselamatan kerja tidak hanya seseorang dapatkan dari institusi saja tetapi bisa juga didapatkan sebelum seseorang tersebut memasuki institusi tersebut. Tingkat pengetahuan keselamatan dan kesehatan kerja cukup (61\%) dengan demikian walaupun pelaksanaan pelatihan keselamatan dan kesehatan kerja dilakukan secara rutin dan diberlakukan di rumah sakit tersebut hal ini dapat disebabkan materi yang disampaikan pada pelatihan K3 belum memadai. Menurut penelitian Sumarto yang dilakukan pada perawat di RSUD Kota Kendari terdapat hubungan bermakna tingkat stres kerja (baik fisik maupun psikis) antara sif kerja pagi, siang, dan malam. hal ini menandakan bahwa stres fisik merupakan salah satu sumber bahaya yang seharusnya perawat ketahui agar mampu menghindari terjadinya kecelakaan kerja. Skor yang rendah pada poin stres fisik dalam kuesioner penelitian ini menjadi faktor tingkat pengetahuan K3 pada mayoritas responden tergolong cukup. Penerapan K3 oleh responden tergolong baik (68\%). Hal ini berhubungan dengan pengetahuan K3 yang cukup, sikap individu yang sudah baik, dan juga informasi K3 yang mereka dapatkan sendiri. Menurut WHO seseorang dapat berperilaku tertentu dalam hal ini adalah upaya untuk menerapkan K3 karena terdapat empat alasan pokok, yaitu pengetahuan, persepsi, sikap, dan kepercayaan. Meskipun pengetahuan K3 yang dimiliki masih dapat dinyatakan tergolong cukup, tetapi tiga alasan pokok lainnya mampu menunjang untuk menerapkan K3 dengan baik sehingga dapat terciptanya penerapan $\mathrm{K} 3$ yang baik dilingkungan rumah sakit.

Usaha yang dapat ditimbulkan dalam menerapakan kesehatan dan keselamatan kerja yang baik dapat dilakukan secara berurutan yang bertujuan untuk membantu dalam mengambil keputusan yang lebih baik dengan melihat risiko terlebih dahulu dan dampak yang kemungkinan ditimbulkan. Tujuan dari melihat risiko terlebih dahulu itu sendiri dapat meminimalkan kerugian dengan urutan yang terdiri dari penentuan konteks, identifikasi risiko, analisis risiko, evaluasi risiko, pengendalian risiko, monitor dan evaluasi, serta komunikasi dan konsultasi. Selain itu, cara yang dapat dilakukan untuk menjaga keselamatan diri sendiri agar terhindar dari kecelakaan kerja salah satunya adalah dengan menggunakan alat pelindung diri yang sesuai standart dan benarbenar aman.Menurut OSHA (Occupational Safety and Health Administration), alat pelindung diri adalah alat yang digunakan untuk melindungi pekerja dari luka atau penyakit yang diakibatkan adanya kontak dengan bahaya (hazard) yang bersifat kimia, biologis, radiasi, fisik, elektrik, mekanik, dan lainnya. Sedangkan berdasarkan Peraturan Menteri Tenaga Kerja dan Transmigrasi No 08/MEN/2010, alat pelindung diri adalah suatu alat yang mempunyai kemampuan untuk melindungi seseorang yang fungsinya mengisolasi sebagian atau seluruh tubuh dari potensi bahaya di tempat kerja. Alat Pelindung Diri (APD) adalah seperangkat alat yang digunakan tenaga kerja untuk melindungi sebagian atau seluruh tubuhnya dari adanya potensi bahaya/kecelakaan kerja (Budiono 2003, p.329). 
Alat Pelindung Diri (APD) dianggap sebagai pertahanan terakhir karena tidak mudah untuk digunakan dan menghambat gerakan (Dinar 2003, p.27). Penggunaan alat pelindung diri pada perawat sangat berpengaruh terhadap penularan penyakit. Apabila perawat tidak menggunakan Alat Pelindung Diri Resiko tertularnya penyakit pada perawat akan semakin bertambah seperti, hepatitis, HIV/AID , sehingga menyebabkan terjadinya resiko infeksi (Potter\&Perry, 2005). Penyakit hepatitis dan HIV/AIDS dapat menyerang perawat apabila tidak menggunakan alat pelindung diri yang disebabkan terkena cairan tubuh atau tertusuk jarum

\section{PENUTUP}

Berdasarkan hasil penelitian di RSUD Kota Kendari, pelaksanaan keselamatan kerja ,hampir semua mengatakan sudah terlaksana tetapi belum tertata dengan baik. Disarankan pihak rumah sakit perlu mensosialisasikan program keselamatan pasien,adanya tim penggerak di ruangan, membuat tim keselamatan pasien, melakukan uji coba disalah satu ruangan, meningkatkan pengetauan hazard dalam pemberian asuhan keperawatan untuk menerapkan keselamatan dan kesehatan kerja ( K3 ) serta mengembangkan langkah langkah yang belum terlaksana. Rumah Sakit yang telah di identifikasi dengan metode HIRARC pada Rumah Sakit bahaya kerja secara umum meliputi bahaya permukaan lantai licin, tergores/tertusuk jarum suntik serta kontaminasi jamur/bakteri/virus saat petugas melakukan tindakan dengan bersentuhan langsung dengan pasien tanpa menggunakan Alat Pelindung Diri (APD), penggunaan produkproduk rumah sakit berbahan kimia, serta kurangnya terpenuhi kebutuhan yang luas untuk ruang kerja dan keluhan klien terkait pelayanan rumah sakit 


\section{DAFTAR PUSTAKA}

1. Salawati L, Herry N, Putra A. Analisis tindakan keselamatan dan kesehatan kerja perawat dalam pengendalian infeksi nosokomial di ruang ICU RSUD DR.Zainoel Abidin Banda Aceh. J Kedokt Syiah Kuala. 2014;14(3):128-34 Handayani, L. T. (2017).

2. Analisis Jalur Keselamatan dan Kesehatan Kerja dengan Kepuasan Terhadap Kinerja Perawat dalam Memberikan Asuhan Keperawatan di RS DI Jember. The Indonesian Journal of Health Science, Vol. 9, No. 1.

3. Dewanti, N. A. Y., Sulistiyani, Setyaningsih, Y., \& Jayanti, S. (2018). Faktor Resiko Tempat Kerja dan Lingkungan Rumah Terhadap Kesehatan Home-based Worker di Kota Semarang.Jurnal Kesehatan Lingkungan Indonesia, 17(1)

4. Restuputri, D. P. (2015). Analisis Kecelakaan Kerja Dengan Menggunakan Metode Hazard and Operability Study (HAZOP). Jurnal Ilmiah Teknik Industri, 14(1)

5. Pratiwi, Nurhantari, Y., \& Budiharjo, S. (2019). Hazard Identification, Risk Assesment and Risk Control Serta Penerapan Risk Mapping pada Rumah Sakit Hewan Prof. Soeparwi Universitas Gadjah Mada. BKM Journal of Community Medicine and Public Health, 35(2), 55-64.

6. Sriningsih, N. \& Marlina, E. (2020). Pengetahuan Penerapan Keselamatan Pasien (Patient Safety) Pada Petugas Kesehatan. Jurnal Kesehatan, 9(1).

7. Yuttya, S. I. (2018). Manajemen risiko k3 menggunakan hazard identification risk assessment and risk control (hirarc). Jurnal kesehatan LP3M Sekolah Tinggi Ilmu Kesehatan (stikes) Cirebon, Vol. 9 No. 1. (e-ISSN: 2721-9518), 4-7. DOI: http://dx.doi.org/10.38165/jk

8. Simamora, R. H. (2011). ROLE CONFLICT OF NURSE RELATIONSHIP WITH PERFORMANCE IN THE EMERGENCY UNIT OF HOSPITALS RSD DR. SOEBANDI JEMBER. The Malaysian Journal of Nursing, 3(2), 23-32.

9. Simamora, R. H. (2020). Learning of Patient Identification in Patient Safety Programs Through Clinical Preceptor Models. Medico Legal Update, 20(3), 553-556.

10. Yuntari, MG. C., \& Nadia, H. (2018). Analisis Resiko Keselamatan dan Kesehatan Kerja Pada Petugas Kebersihan di Rumah Sakit. Faletehan Health Journal, 5(3), 107-116.

11. Sandewa, S. Adhiwijaya, A. (2014). Hubungan perilaku dengan resiko kecelakaan kerja pada perawat di ruang rawat inap RSUD labuang baji makassar. Jurnal Ilmiah Kesehatan Diagnosisi, 5(4), 500-506. 